\title{
Management Implementation Analysis of Centralization Education and Training Student Sport Sepak Takraw Central Java
}

\author{
Andhika Yahya Putra ; Siswandari Siswandari; Sapta Kunta Purnama \\ Department of Sport Science, Sebelas Maret University, Indonesia \\ Email: andhika.yahya.putra@gmail.com
}

http://dx.doi.org/10.18415/ijmmu.v5i4.287

\begin{abstract}
This study objective is to know: 1) Organization structure PPLOP Central Java sepak takraw; 2) The stage process in athlete recruitment at PPLOP Sepak Takraw Central Java; 3) Facility and infrastructure management in supporting PPLOP sepak takraw athlete achievements Central Java; 4) Implementation of management financial at PPLOP Sepak Takraw Central Java; 5) Implementation of Training Management PPLOP sepak takraw Central Java. This study is conducted in Association of PPLOP Sepak Takraw Central Java. This study is using descriptive qualitative method. The technique of data collection is documentation, in-depth interviewing, and observation. The data source is manager, coach, and PPLOP sepak takraw central java athlete. The management implementation of PPLOP Sepak Takraw Central Java has been good overall; 1) Organization Structure of PPLOP Sepak Takraw has been good, in which already has elements of the organization that keep trying to facilitate athletes to achieve; 2) The athlete recruitment process is poorly run so that PPLOP must do planning and coordination back to KEMENPORA so that recruitment process can be done well in the future; 3) The facilities and infrastructure needed are in accordance with the needs of the Student Athlete, this is because the managers, trainers, athletes can maximize and streamline existing facilities and can utilize the tools in accordance with the needs of the students PPLOP; 4) Implementation of financial management has been well implemented. Judging from the management of funds and financial reporting by seeing the existing needs are running well; 5) Implementation of exercise management at the Center for Training and Student Sports Exercise has traveled well, the management only maximizes the available funds.
\end{abstract}

Keywords: Implementation of PPLOP Management; Organization Structure Of PPLOP; Athlete Recruitment; Facility And Infrastructure Management; Financial Management; Training management;

\section{Introduction}

Sport is one of a manifestation of efforts to improve human quality aimed at the creation of character and personality, discipline and high sportsmanship, and the improvement of achievement that can arouse national pride. Besides that, achievements are the benchmark of a nation's progress that has a very important role for the effort of forming and improving the quality of human resources for development. 
The coaching and development process of sports achievement is certainly required athletes who have high potential. To get potential athlete, the coaching and development of achievement are needed, exactly in school age level. Based on those orientations, the government set up coaching model in student, namely student Diklat. This spreads on certain province in Indonesia, which has student as objective, namely Student Sport Education and Training Center (PPLP). Nowadays it becomes PPLOP, which is going to be the target for forerunner of the emerging athletes in the future.

On the journey of PPLP which has been relatively long time, and now PPLP is changed to PPLOP. Amount of junior athletes was succeeded to contribute for Indonesia in regional and international. One of sport, which contribute junior athlete, is Sepak takraw. PPLOP has been participated in several competitions such as POPNAS (National Student Sports Week) which is held biennial on the odd year, POPWIL (Regional Sports Week) which is held biennial on the even year, KEJURNAS (National Championships) which is held yearly. In those competitions, the PPLOP athlete will show the best performance to compete with other regional and prove their daily training succeeded or not. In fact, POPNAS, POPWIL, and KEJURNAS Sepak takraw from 2007 until now (2017) PPLOP Sepak takraw Central Java is always be winner. On the other side, facilities and infrastructure is poor. The dorm and training court is still not standard. PPLOP sepak takraw central java need to be paid attention. It should be another factor that makes PPLOP sepak takraw central java always be winner with minimum facilities and infrastructure for athlete.

Based on the previous background, it can be found problem statement, that is: How the organization structure of PPLOP sepak takraw Central Java, How the stage process in athlete recruitment at PPLOP Sepak Takraw Central Java, How the facility and infrastructure appropriate to the student athlete need, how the implementation of management financial at PPLOP Sepak Takraw Central Java, How the implementation of training management PPLOP sepak takraw Central Java.

\section{Methodology}

The type of research is qualitative study and descriptive. This research takes the problem condition of the management implementation PPLOP sepak takraw Central Java, which is presented descriptive. This research is not a statement of numbers and not in the form of numbers.

This research is conducted in Association of PPLOP Sepak Takraw Central Java. The technique of sample collection used is purposive sampling and snowball sampling. The data source of this study is management, coach and PPLOP sepak takraw Central Java athlete. The technique of data collection is conducted with reviewing data and content analysis, in-depth interviewing, observation. Then, conducted data reduction for focusing, simplifying and then conducted descriptive in the form of narrative that allows the research conclusion can be done. Whereas, to establish the data validity is used examination techniques with four criteria, namely credibility, transferability, dependability, and confirmability. The data analyzed qualitatively derived from data obtained from various sources of interviews. The stage of data analysis conducted in this research, as follows: 1) Data collection; 2) data presentation; 3) Data reduction; 4) Drawing Conclusion/Verification.

\section{Results}

Based on all of research steps and data collection from variety sources, which is found by the researcher, the researcher finds some data, which support to reveal important results in this research. This data aims to answer the problem statement or to give valuable information for everyone who needs it. The data finding from variety sources can be seen as follows: 


\section{Organization Structure of Sepak Takraw PPLOP in Central Java}

PPLOP has an important position in the framework of achievement coaching thoroughly. Organizationalally, the process of achievement in PPLOP has a relation between formal education in school and sports achievement. In addition to that PPLOP is a Ministry of Youth and Sports program which in its implementation required coordination with various related parties who have competence and special authority on the subject of the program. Coordination within the PPLOP organization is necessary to obtain optimal support from various stakeholders as an accomplished athlete user.

Organizations are said to be good if in an organization already has a complete stewardship, and can work together well and compact, in terms of management there is a good cooperation between local and local government officials. But there are few constraints that need adjustment when there is a change of leader. It is natural and does not constitute a significant problem and organizational structure.

\section{Stages of Sepak Takraw Athlete PPLOP Recruitment in Central Java}

The description of the implementation of the stage process undertaken in the recruitment of student athletes in PPLOP Sepak Takraw Central Java above, indicates that the process of stages performed in the recruitment of athletes has not gone well. It can be seen from the promotion is not running well, it is seen from the participants who register only consists of several districts/ cities only. Possible due to lack of socialization from PPLOP managers in this case the Department of Youth Sports and Tourism of Central Java to the existing schools in the Central Java District or the location of the district/ city making it difficult for prospective participants to register or not get information. This is because DISPORAPAR province submits directly to similar service in kab/ kota to accommodate the registration while the office of $\mathrm{kab} /$ kota less socialize.

During this process of recruitment of athletes 30\% tend to be taken from POPDA results, but the results are not necessarily guarantee athletes can be fostered and achievers as expected. Then at the time of recruitment process not all the test stages are done coherently by the manager in accordance with the guidebook of the determination of the test parameters referring to the Center for Training and Training of Students and Special School Athletes issued by Assistant Deputy of Achievement and Science and Sports Science of the Ministry of Youth and Sport of the Republic of Indonesia Year 2006. Only a few tests conducted by PPLOP managers Sepak Takraw Central Java in accordance with the bench mark issued by KEMENPORA. So the tests performed during just the test of Vo2 max Bleep test are replaced with Balke test, Upright jump, sit-up, push-up, shutle run, 30 meter run. Managers provide reasons not all tests are conducted in Athlete recruitment because equipment is inadequate if used. Then another constraint, most athletes sent by regencies/ cities 50\% are not athletes, and 50\% are beginners athletes from sports clubs. Seen from the symmetrical body (anthropometry), there are still many districts sending athletes with a height still below average. It seems that the Regency/ City in general is unclear about how to find an athlete who can support the sport of achievement. While it is very clear, high achievement can only be achieved by athletes who have great talent and get good coaching in stages and continuous. Then to produce and have the potential for sporting achievements as high as in the future, it is necessary to find and find talented athletes.

Furthermore, the guidebook which has been issued by Kemenpora through Deputy of Achievement Improvement and Science and Sport Science emphasized that in tiered achievement counseling has implication to the importance of evaluation which must be done periodically from the stage of athlete screening until the final stages of the implementation of training program and achievement. The purpose of this manual is to reduce diversity and ensure the quality of parameters and instruments used to evaluate athletes, it is necessary to have a Central Management Manual as a reference. 
Based on the guidebook issued by the Deputy of Improvement of Achievement and Science and Sport Science in 2006 that is in conducting the test, need to pay attention to the order of measurement implementation. Types of measurements that require the athlete to exercise a great deal of energy should be carried out in the final sequence, such as aerobic capacity measurement, maximal aerobic capacity and physical fitness Guide on Parameter Testing Establishment at the Center for Training and Training of Special Students and Schools of Athletes. In this case PPLOP Sepak Takraw Central Java on the recruitment of student athletes was not fully refer to the guidebook of the determination of test parameters issued by the Deputy of Achievement and Science and Science and Sport Science KEMENEGPORA 2006.

Should PPLOP Sepak Takraw Central Java in this case the Head of Balai do re-assessment of the recruitment process that has been done. Then do the planning and coordination back to KEMENPORA in this case the Deputy of Achievement Improvement and Science and Sport Science in the process of recruitment of future PPLOP athlete candidate, and also supervision from Deputy of Achievement Improvement and Science and Sport Science during the process of recruitment of PPLOP athlete candidate Sepak takraw Central Java. In order to find a talented athlete and have the greatest potential sports achievement in the future, as expected by KEMENPORA.

\section{Implementation of Facilities and Infrastructure Management Sepak Takraw PPLOP in Central Java}

The From the above findings, the procurement plan has been prepared in the work program of Head of PPLOP Center for Central Java. Determination of goods or facilities to be purchased discussed with all managers PPLOP Sepak Takraw Central Java. Such as the inventory/ training tool, the athlete's boarding equipment needs and facilities, the finance staff equipment, the administration, the cleanliness and the safety of the dormitory environment and others. Utilization of training facilities and infrastructure has been optimal as the training tools in PPLOP Sepak Takraw Central Java. Likewise with the storage of existing exercise equipment tailored to the place (after exercise tools are returned). Recording and reporting already exists such as used equipment inventory books, goods list, acceptance and use of goods. Reports are conducted in line with the report smesteran or 6 months.

Description of the implementation of PPLP facilities management and infrastructure The above Central Java pencak silat shows that it is assessed from the implementation of all activities already underway which include planning, organizing or providing, utilizing or utilizing, storing or maintaining and recording data or reporting.

Maintenance, maintenance of sports facilities and infrastructure is good enough. This is evident from the cleanliness and orderliness of PPLOP Sepak Takraw Central Java. The arama building uses a 2story system so that the courtyard or dormitory can be used for athletes to practice and play. But the infrastructure of the Center for Training and Student Sports Exercise (PPLP) Central Java pencak martial arts training has not been entirely good, meaning that the training infrastructure supports only $60 \%$ of the overall sport. Other supporting equipment is not adequate, such as the lack of wight training or other equipment supporting the exercises, especially the use of training tools. Whereas for the management of infrastructure and facilities in PPLOP can be interpreted as follows:

a. Infrastructure and facilities used in the implementation of the Center for Student Sport Education and Exercise (PPLOP) are required to meet National type, number and standard.

b. The standardization of sports infrastructure and facilities used for the PPLOP should be adjusted to National standards. 
How can PPLOP Sepak Takraw Central Java achieve an achievement both at National and International level, if the training infrastructure alone is not fully support to practice. Exercise infrastructure is very important and very supportive in supporting athletes achievement. As Adhyaksa (2004) notes, "it is realized that the decline of Indonesia's sporting achievements is not separated from such aspects as the low government's attention to Indonesian sport and the limited sports facilities and infrastructure, the lack of regular competition and the lack of appreciation for outstanding athletes".

So, until now, PPLOP Sepak Takraw Central Java only maximize existing infrastructure only in achievement. Therefore, it is necessary to have planning and assessment from PPLOP and coordinate with local government and KEMENPORA in this case the attention to complete the infrastructure training facilities in PPLOP Sepak Takraw Central Java so that potential athletes in sports achievement can be realized.

\section{Implementation of Financial Management}

Implementation of Financial Management shows that APBN through Deconcentration fund and APBN already done as scheme. Deconcentration fund is budgeted by Youth and Sport Ministry to Department of Youth Sport and Tourism (DISPORAPAR) Central Java to guide the Sepak Takraw athlete of PPLOP in Central Java by Sepak Takraw association of Centralization Student Education and Training Sport in Central Java and aid to join the championship between PPLOP which manage by Province Administrator BAPOPSI of Sepak Takraw in Central Java, than APBD earmarked to financing the maintenance of Sepak Takraw hostel in Central Java.

APBD fund PPLOP Sepak Takraw Central Java earmarked to hostel operational finance. Deconcentration is divided into two types:

a. Development of PPLOP Sepak Takraw Central Java

1) Other Non-Operating Goods:
a) Exercise Equipment;
b) Procurement of School Shoes;
c) Procurement of School Uniforms;
d) Health

2) Material Shopping
a) Supply of ATK;
b) Documentation and Reports;
c) Computer Equipment;
d) Athlete Consumption

3) Other Shopping Services

a) Coach and Massage Services;

b) Boarding Service; 
c) Security Management Services;

d) PPLOP Management Services;

e) Stakeholder Meetings Service;

f) Athlete Services

4) Other Travel Shopping in the Country

a) Caller Transport/ Repatriation;

b) Local Transport Trainers;

c) Transports Try Out

5) Championships between PPLOP

a) Athlet Pocket Money;

b) Coach and Official Allowance;

c) Documentation and Reporting;

d) ATK;

e) Cost of the Championship Transportation

b. Shopping Area

1) Cost of Cleaning Services;

2) Telephone Account Fees;

3) Water Shopping;

4) Electricity Cost;

5) Shopping Materials Drugs;

6) Shopping Materials Auxiliary;

7) Shop for School Clothes;

8) Sportswear Shopping;

9) Athlete's Expense Charge;

10) Capital Expenditure on Construction Procurement/ Building Rehab

Financial management activities in this association PPLOP Sepak Takraw Central Java can be executed by using facilities in the PPLOP, using special power in financial field which handle money income and outcome to operational needed of PPLOP Sepak Takraw Central Java. Since this PPLOP belongs to the Government, all funds are completely from the government and local government.

The illustration of financial management implementation above shows that based on the all of activities implementation view and fund source from the center government and local government are 
relatively good. However, fund deconcentration allocation and APBD have limitation, so administrator only maximizing the fund to manage PPLOP Sepak Takraw Central Java.

In the implementation, financial management development PPLOP Sepak Takraw Central Java is managed by association Sepak Takraw of PPLOP Central Java who has responsibility to Youth and Sport Ministry of RI through Department of Youth Sports and Tourism of Central Java Province and Local Government.

The Financial Management Mechanism Development of PPLOP Sepak Takraw Central Java is given through direct assistance whereby DISPORAPAR appoints directly to the Central Kalimantan Education and Training Center (PPLOP) Sepak Takraw Central Java, that the management unit should receive assistance in completing the following requirements:

a. SK Formation Association of PPLOP;

b. Notaries Deed;

\section{c. Proposal for PPLOP Activities}

After the file is completed, a letter of cooperation agreement is made to be able to withdraw the fund.

The mechanism of fund withdraw assistance, the first step of making the proposal and approved by the authorized use of budget then the issuance of cooperation agreement (SPK). Issuance of receipts in accordance with the request contained in the letter of cooperation agreement (SPK), then Youth and Sports Training Development handed the responsibility to the Treasurer receipt of expenditure.

Then the responsibility file submitted to KPKN Chairman of Association for PPLOP Sepak Takraw Central Java, as a manager, serves as an authorizer, and overflowing authorizer function to order payment for the construction process PPLOP Sepak takraw Central Java. Nevertheless, it is not justified to carry out the functions of the treasurer, also overflowing coordinator functions to test the right to pay for the development process of PPLOP Sepak Takraw Central Java.

In PPLOP Sepak Takraw Central Java, the Head Association for PPLOP is a manager who has functions as an authorizer, benefactor, but only extracurricular money management. Thus the Head Association of PPLOP Sepak Takraw Central Java in performing their duties only from the utilization of fund, the participation of trainers in financial management that has been implemented well. The management of financial management which includes: Preparation of PPLOP budget planning for Sepak Takraw Central Java, procurement and funding sources, utilization of funds, responsibility and accountability of financial data PPLOP Sepak Takraw Central Java, then financial management Association for PPLOP Sepak Takraw Central Java in the future will be able to be success, orderly, and regularly, as well as achieve the development purpose of PPLOP Sepak Takraw Central Java. It is because financial management is one of the direct resources that support the achievement of PPLOP development process Sepak takraw Java Central and this is very decisive potential for the implementation of PPLOP Sepak Takraw Central Java, along with other components.

\section{The Training Program Planning of PPLOP Sepak Takraw Central Java as Expected by KEMENPORA}

Implementation of program planning in Central Centralization Student Education and Training Sport Sepak Takraw Central Java has been running well, it has gradually shown the achievement of the target as expected by KEMENPORA. That is the Establishment of PPLOP as an alternative to conduct development and improve talented athletes and high interest in sport to be developed in order to achieve 
optimal performance, both as a regional sportsman which is representing the region and become one of the national athlete to represent nation and country in international sport event. (Deputy of Achievement and Science and Technology and Sports: 4) PPLOP also has a goal of producing national sport achievers in sport and academic.

One of the training program planning is conducting Try Out which refers to the mannual by the Deputy of Achievement and Science Technology and Sports of the Ministry of Youth and Sports that Exercise, Competition, Academic and Welfare is regulated i.e. competition;

a) Competition of sports between PPLOP carried out periodically

b) Every activity of national sport competition inter-PPLOP must be followed by all PPLOP

c) Local Government that is designated as the organizer is responsible for the implementation of competition inter-PPLOP by involving the parent organization and society

Although there are some constraints, like not doing try out because of minimity competition and limited fund. Seldom the match schedule and PPLOP program are incompatible. The match/ competition schedule often arise suddenly while the training program is still running. Often the schedule is delayed, PPLOP athletes is not military/ police which can be ready anytime.

\section{Conclusion}

Based on the data analysis and discussion, the researchers have found important inventions, as follows:

1. PPLOP Organization Sepak Takraw has been good, in which already has elements of the organization, such as leadership and organization management, household basic budgets, and budget funds. All of elements have been implemented well, already has a complete stewardship, and can work together well and compact, in terms of management there is a good cooperation between local and regional government officials. But there are few constraints that need adjustment when there is a change of leader. It's natural and it does not matter much.

2. The implementation of the stage process done in the recruitment of athletes in PPLOP Sepak Takraw Central Java is not running well, it is seen from the participants who register only consists of several districts/ cities only. This is due to the lack of socialization from PPLOP managers in this case the Department of Youth Sports and Tourism of Central Java to the existing schools in Central Java District/ City. Athlete recruitment process 30\% tends to be taken from POPDA results, but the results are not necessarily guarantee athletes can be fostered and achievers as expected. We recommend PPLOP Sepak Takraw Central Java in this case the Head of Balai do re-assessment of the recruitment process that has been done. Then do the planning and coordination back to KEMENPORA in this case the Deputy of Improvement of Achievement and Science and Sport Science in the process of recruitment of future PPLOP athlete candidate, and the supervision of Deputy of Achievement Improvement and Science and Sport Science during the process of recruitment of PPLOP athlete candidate Sepak takraw Central Java. In order to find a talented athlete and have the highest potential for sports achievement in the future, as KEMENPORA expects.

3. The facilities and infrastructure needed are in accordance with the needs of the Student Athlete, this is because the managers, trainers, athletes can maximize and streamline the existing facilities and can utilize the tools in accordance with the needs of the students PPLP. Although basically the infrastructure facilities still not fully meet the standards. 
4. The implementation of financial management has been working properly. It can be seen on fund management and financial report. Although there is a constraint, the manager can overcome the financial problem.

5. The planning of training program in PPLOP Sepak Takraw Central Java is appropriated to KEMENPORA expectation. Based on the finding above, it can be drawn that the implementation of program planning at PPLOP Sepak Takraw Central Java has been running well and reaching the KEMENPORA target, that is the Existing PPLOP as alternative to conduct coaching and improving the potential student agree with passion and interest in sport in order to reach optimal achievements result, both of regional athlete which is representing region, in spite of the athlete group which are representing nation in international sport championships.

\section{Acknowledgemnt}

To the head of PPLOP Central Java, trainers, administrators, and athletes PPLOP Sepak takraw Central Java who has helped in the research process.

\section{References}

Adhyaksa Dault. (2004). Hal Aktual Keolahragaan Indonesia. Jakarta: Majalah Forum Olahraga Diknas.

Aip Syarifudin. (1992). Atletik. Jakarta, Depertemen Penelitian dan Kebudayan Direktorat Jenderal Pendidikan Tinggi Proyek Pembinaan Tenaga Pendidikan.

Alisjahbana. (2008). http://fptijateng.multiply.com/journal/item/305 Sistem Pembinaan dan Reformasi Bangunan Keolahragaan Nasional.

Ambar T.Sulistiyani Rosidah. (2003). Manajemen Sumber Daya Manusia: Konsep, Teori dan Pengembangan dalam Konteks Organisasi Publik. Yogyakarta: Graha Ilmu.

Ambarukmi, D. A. dkk. (2007). Pelatihan Pelatih Fisik Level I. Deputi Bidang Peningkatan Prestasi dan IPTEK Olahraga. Kemenpora.

Deputi Binpres \& IPTEK Olahraga Kemenegpora. (2006). Petunjuk Pelaksanaan dan Teknis Penyelenggaraan PPLP. Jakarta: Kemenegpora

Direktorat Jenderal Olahraga Departemen Pendidikan Nasional. (2004). Pedoman Manajemen Organisasi Olahraga.

Fatah, Nanang. (2003). Landasan Manajemen Pendidikan. Bandung : PT Remaja Rosdakarya.

Handoko, T Hani. (2001). Manajemen Personalia dan Sumberdaya Manusia. Yogyakarta: BPFE Yogyakarta.

Harsuki. (2003). Perkembangan Olahraga Terkini, Kajian Para Pakar. Jakarta: PT Raja Grafindo Persada.

Hasibuan, S.P Malayu. (2005). Manajemen Sumber Daya Manusia. Edisi Revisi. Jakarta: Bimi Aksara.

Husdarta. (2009). Manajemen Pendidikan Jasmani. Bandung: Alfabeta.

Junusul Hairy. (2000). Fisiologi olahraga. Jakarta: Deparemen Pendidikan dan Kebudayaan. 
Kamiso. (1991). Ilmu Kepelatihan Dasar. Semarang: FPOK IKIP Semarang.

Kristiyanto, Agus. (2012). Pembangunan Olahraga Untuk Kesejahteraan Rakyat Dan Kejayaan Bangsa. Surakarta: Yuma Pustaka.

Lutan, Rusli dan Suherman, Adang. (2000). Perencanaan Pembelajaran Pejaskes. Jakarta: Depdiknas.

Marihot Manullang, dearkina Sinaga. (2005). Pengantar Manajemen Keuangan. Yogyakarta: ANDI.

Moleong, Lexy J. (2000). Metodologi Penelitian Kualitatif. Bandung: PT. Remaja Rosdakarya.

Mulyasa, E. (2005). Menjadi Kepala Sekolah Profesional. Dalam Konteks Menyukseskan MBS dan KBK, Bandung: Rosda Karya.

Noer, A. Hamidsyah. (1996). Kepelatihan Dasar. Jakarta: Pusat Penerbitan Universitas Terbuka Pendidikan dan Kebudayaan.

Republik Indonesia, Undang-undang No. 16 tahun. (2007). Tentang Penyelengaraan Keolahragaan.

Sajoto. (1995). Peningkatan dan Pembinaan Kekuatan Kondisi Fisik dalam Olahraga. Semarang: Dahara Prize.

Siagian, P Sondang. (2007). Manajemen Sumber Daya Manusia, Jakarta: PT. Bumi Aksara.

Subardjah. (2000). Bulutangkis. Bandung: Depdikbud.

Sudjarwo. (1993). Ilmu Kepelatihan Dasar. Surakarta: UNS Press.

Suhendro, Andi. (1999). Dasar-Dasar Kepelatihan. Cetakan Ketiga. Jakarta: Unuversitas Terbuka. Departemen P\& K.

Tangkudung, James. (2006). Kepelatihan Olahraga "Membina Prestasi Olahraga". Jakarta: Cerdas Jaya.

Wahjosumirdjo. (2003). Kepemimpinan Kepala Sekolah, Tinjauan Teoriti dan Permasalahannya. Jakarta: PT Raja Grapindo Persada.

\section{Copyrights}

Copyright for this article is retained by the author(s), with first publication rights granted to the journal.

This is an open-access article distributed under the terms and conditions of the Creative Commons Attribution license (http://creativecommons.org/licenses/by/4.0/). 